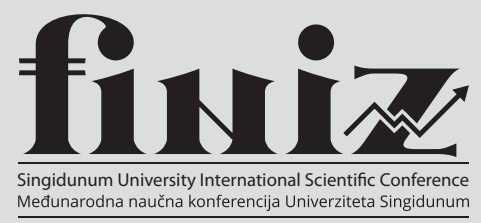

CONTEMPORARY

FINANCIAL MANAGEMENT

UPRAVLJANJE FINANSIJAMA U

SAVREMENIM USLOVIMA

POSLOVANJA

DOI: 10.15308/finiz-2015-62-68

\title{
RAZLIČITE ULOGE I ODGOVORNOSTI INTERNE I EKSTERNE REVIZIJE
}

\author{
Mile Stanišićc \\ Univerzitet Singidunum, Danijelova 32, Beograd, Srbija
}

\section{Apstrakt:}

Rukovodstvo preduzeća ne pravi veliku razliku između uloga i odgovornosti interne i eksterne revizije, zbog čega često dolazi do poistovećivanja aktivnosti interne revizije sa eksternom revizijom. U takvim okolnostima interna revizija nije dovoljno efikasna i ne doprinosi ostvarivanju ciljeva organizacije, jer se često poistovećuje sa eksternom revizijom, iako su to dve različite profesije. Kako bi se rešio problem nedovoljne efikasnosti interne revizije u takvim organizacijama neophodno je krenuti od sagledavanja pojedinačnih ciljeva interne i eksterne revizije. Osnovna aktivnost obeju revizija jeste davanje uveravanja. Suštinska razlika je u onome o čemu se daju uveravanja, koja uveravanja daju i kome ih daju, kao i u kom vremenskom periodu. Dok eksterna revizija daje uveravanje o istinitosti i objektivnosti finansijskih izveštaja, interna revizija daje uveravanje o efektivnosti i efikasnosti upravljanja rizicima, internim kontrolama i procesima rukovođenja u odnosu na celokupno poslovanje organizacije, a ne samo u oblasti finansijskog izveštavanja. Dakle, neophodno je definisati zasebno predmet i ciljeve interne i eksterne revizije, kao i kako se uspostavljaju i nadziru njihove odgovornosti.
\end{abstract}

\section{Ključne reči:}

interna revizija,

eksterna revizija,

uloga revizije,

odgovornost revizije.

\section{UVOD}

U proteklih deset godina u bankama, preduzećima, javnim institucijama Republike Srbije ustanovljava se funkcija interne revizije. Glavni problem mnogih funkcija jeste $u$ tome što revizori nisu dovoljno razumeli zadatke interne revizije i zbog toga nisu adekvatno determinisali njen delokrug. Mnogi su svoje zadatke posvetili samo računovodstvenoj oblasti i finansijskim izveštajima, odnosno poistovetili su svoje zadatke sa zadacima eksterne revizije.

Revizor je revizor...tačno? Pa, u stvari i nije tačno. Svakako, da bi dešifrovali šta je pogrešno kada se stvari ne odvijaju kako treba, svi revizori moraju da imaju oštro oko; moraju da prepoznaju mesta neefikasnosti i neefektivnosti; moraju da poseduju hrabrost i uverenje da se suoče sa osetljivim pitanjima; moraju da obezbede model beskompromisnog integriteta i etike; i moraju da budu nepopustljivi (nemilosrdni) u svojoj posvećenosti (obavezi) da prodru do dubine (suštine) stvari. Mada je sve ovo tačno, pravila koja se primenjuju, standardi koji se poštuju, i uloge koje se zahtevaju od internih, eksternih i državnih revizora su u stvari sasvim različiti.

Opšta javnost bi lakše razumela ulogu revizora, ukoliko bi u njihovim poslovnim (vizit) kartama bio prikazan jednoobrazni (jedinstven) naziv umesto svih naziva koji uključuju naziv „revizor”. Zbog sličnosti koje se uočavaju, u ovom
Što se tiče sledećeg pitanja koje se odnosi na Atmosferu na vrhu fokusiraćemo se na zamršenosti interne revizije, koja se uprkos zajedničkim karakteristikama i ciljevima u velikoj meri razlikuje od eksterne revizije. Međutim, u ovom radu nameravamo da prikažemo na koji način se interni i eksterni revizori razlikuju i da razjasnimo uobičajena pogrešna shvatanja (mišljenja) u pogledu njihovih uloga i odgovornosti. U ovom radu se neće tretirati i državna revizija, jer je ovde problem efektivnosti i efikasnosti interne revizije i njene zamršenosti sa eksternom revizijom.

\section{MISIJA INTERNE I EKSTERNE REVIZIJE}

Misija interne i eksterne revizije izvodi se iz njihovim definicija. Institut internih revizora (IIA, str. 2) je dao definiciju iz koje se izvodi misija interne revizije. Definicija interne revizije, koju je Institut internih revizora dao 1999. godine glasi:

"Interna revizija je nezavisno, objektivno uveravanje i savetodavna aktivnost osmišljenja da doda vrednost i poboljša poslovanje organizacije. Ona pomaže organizaciji da ostvari svoje ciljeve uvodeći sistematičan, disciplinovani pristup procenjivanju i poboljšanju aktivnosti upravljanja rizikom, kontrolnih i upravljačkih procesa."

Iz definicije proizilazi da je cilj interne revizije da doda vrednost i poboljša poslovanje organizacije. $U$ definiciji interne revizije se jasno navodi da proces interne revizije pomaže 
da organizacija ispuni svoje ciljeve sistematskim i stručnim pristupom da bi se ocenila $i$ unapredila efikasnost procesa upravljanja rizikom, kontrole i upravljanja. Na bazi ove definicije odeljenje za internu reviziju može i treba da predstavlja resurs koji pomaže da odbor za reviziju utvrdi pravi nivo i uključenost radnih zadataka (dužnosti) interne revizije.

Ako je cilj interne revizije da poboljša poslovanje organizacije, da li je to cilj i eksterne revizije? Glavni cilj eksterne revizije je revizija finansijskih izveštaja, a Međunarodni standard revizije ISA 200 definiše cilj revizije finansijskih izveštaja (IFAC, 2007, str. 215):

"Cilj revizije finansijskih izveštaja je da omogući revizoru da izrazi mišljenje da li su finansijski izveštaji, po svim bitnim pitanjima, sastavljeni u skladu sa utvrđenim okvirom za finansijko izveštavanje."

Iako mišljenje eksternog revizora povećava poverenje u finansijske izveštaje, korisnik to mišljenje ne može da tumači kao uveravanje o budućoj vitalnosti pravnog lica, niti može da da uveravanje o efikasnosti i efektima vođenja poslova od strane rukovodstva tog pravnog lica. Suprotno tome interna revizija daje mišljenje o efektivnosti i efikasnosti upravljanja rizicima, procesima kontrole i procesima upravljanja. Dakle, ove dve profesije daju potpuno različita uveravanja. Naravno, pored različite vrste uveravanja, otvara se i pitanje kome se daju uveravanja, ko su korisnici toga uveravanja i čemu služe ta uveravanja. Iz svega toga proizilaze različite uloge i odgovornosti profesije interne i eksterne revizije.

Zakon o reviziji (Zakon, 2013, član 2) definiše da je revizija finansijskih izveštaja postupak provere i ocene finansijskih izveštaja, kao i podataka i metoda koji se primenjuju pri sastavljanju finansijskih izveštaja, na osnovu kojih se daje nezavisno stručno mišljenje o tome da li finansijski izveštaji u svim materijalno značajnim aspektima daju istinit i pošten prikaz finansijskog stanja i rezultata poslovanja pravnog lica u skladu sa odgovarajućom regulativom za izradu finansijskih izveštaja. Dakle, ovde se radi o zakonskoj reviziji redovnih godišnjih i konsolidovanih finansijskih izveštaja od strane društva za reviziju.

Problem koji je uvek postojao kada se radi o izveštaju menadžera vlasnicima (investitorima) jeste da li vlasnici (investitori) mogu da veruju u izveštaj? Izveštaj može da sadrži greške, da bude namerno obmanjujući ili da nije u skladu sa propisima. Rešenje ovog problema je da se imenuje revizor koji će ispitivati informacije i izveštaj. $\mathrm{Na}$ taj način revizijom se smanjuje rizik da finansijske informacije budu netačne, nepotpune i pristrasne. Sveobuhvatni cilj revizije je da unapredi kredibilitet finansijskih izveštaja smanjenjem rizika kada su u pitanju informacije (Millichamp, 2002).

Porter et al. (2003, str. 13) definišu reviziju kao:

"Sistematski proces objektivnog sakupljanja i ocenjivanja dokaza koji se odnose na tvrdnje o ekonomskim aktivnostima i događajima u kojima organizacija, koja prezentira tvrdnje, učestvuje da bi se obezbedio stepen saglasnosti između tih tvrdnji i utvrđenih kriterijuma."

Gray \& Manson (2000, str. 17) definišu reviziju finansijskih izveštaja koju obavlja eksterni revizor kao:

"Istraživanje dokaza koji će omogućiti da se formira mišljenje o istinitosti i objektivnosti finansijskih i drugih informacija od strane jedne ili više osoba nezavisnih u odnosu na onog ko priprema te informacije i osoba koje će verovatno direktno koristiti informacije, i izdavanje izveštaja o tim in- formacijama sa ciljem da se poveća njihov kredibilitet a time i njihova korisnost."

$S$ druge strane, interna revizija mora da obezbedi menadžmentu dinamičan i koristan alat koji će obezbediti pozitivan doprinos ostvarenju ciljeva organizacije. Interna revizija treba da asistira menadžmentu u raspodeli odgovornosti rukovođenja tako što će identifikovati rizike i obezbediti:

- Objektivne ocene poslovnih rizika,

- Redovne procene sistema kontrole organizacije,

- Efektivne izveštaje operativnih i finansijskih performansi.

Uloga interne revizije je u asistenciji menadžmentu kako bi se maksimizirale mogućnosti i minimizirale pretnje po organizaciju. Interna revizija mora da opravda poverenje nadzornog odbora, komiteta za reviziju i menadžmenta i da doprinese stalnom unapređenju strategije organizacije. U promenljivoj i sve konkurentnijoj sredini neophodno je da se dobije maksimum iz funkcije interne revizije. Doprinos funkcije interne revizije ostvarenju ciljeva organizacije mora stalno rasti uz istovremeno očuvanje nezavisnosti i ugleda.

\section{ULOGE I ODGOVORNOSTI}

Nadzorni odbor, izvršni menadžment, interni revizori i eksterni revizori predstavljaju osnovu efikasnog korporativnog upravljanja. Uloge i odgovornosti svakog od ovih temelja često se pojavljuju donekle zamršeno i zbunjujuće, posebno u današnjoj poslovnoj areni sa povećanim brojem propisa i većim očekivanjima od korporativne odgovornosti.

Dok su eksterni revizori prvenstveno zainteresovani za reviziju finansijskih izveštaja, interni revizori su imali potrebu da procenjuju sveukupno poslovanje. „Saradnja između eksternih i internih revizora je značajna, jer ona unapređuje ekonomiju, efikasnost i efektivnost ukupne revizorske aktivnosti za preduzeće. Nijedan oblik revizije ne može da bude zamenjen drugim, ali oni na mnogo načina utiču jedni na druge. Ukoliko ove dve revizije nisu koordinisane biće preklapanja i dupliranja koja nepotrebno povećavaju troškove revizije.”

IIA podstiče svoje članove i druge stručnjake interne i eksterne revizije da se ozbiljno prihvate zadatka da pomognu da se razjasne pogrešna shvatanja (mišljenja), koja se odnose na internu i eksternu reviziju. U osnovi, ovo su dve različite profesije od kojih svaka donosi veliku vrednost organizaciji i njenim učesnicima (stejkholderima). Kada se obavljaju nezavisno, objektivno i u skladu sa standardima; u skladu sa pravilima i propisima; i uključujući odgovarajuću saradnju; obe profesije mogu na efikasan način da ispunjavaju svoje osnovne uloge upravljanja i pozitivno da utiču na poverenje javnosti.

Primarna odgovornost eksternih revizora je provera finansijskih izveštaja organizacija. Cilj je da se odrediti da li iskazi istinito prikazuju finansijski položaj organizacije i rezultate njenih aktivnosti za određeni period. Takođe, eksterni revizori se moraju uveriti da su izveštaji sastavljeni u skladu sa opšte prihvaćenim računovodstvenim načelima, da se primenjuju isti principi kao i prethodne godine i da je imovina očuvana.

Eksterni revizori su zakonski obavezni da izdaju izveštaj o „istinitom i objektivnom” prikazivanju finansijskih izveštaja (zakonski propisanog završnog računa). Izveštaj može da uključuje različite vrste mišljenja zavisno od nalaza u reviziji finasijskih izveštaja i odgovarjućih kontrola, predloženih 
korigovanja finansijskih izveštaja, mogućnosti nastavljanja poslovanja organizacije (going concern). Od eksternih revizora se zahteva: da traže pismo o predstavljanju da bi uticali na CEO i CFO, da budu svesni svojih obaveza i da obezbede da sve relevantne informacije budu dostavljene pre izdavanja ovog izveštaja.

Interni revizori imaju drugačiju funkciju. Ona je šira i dublja nego kod eksternih revizora. Njihova funkcija je da menadžere širom organizacije snabdevaju informacijama koje su potrebne da bi efektivno ispunili svoje obaveze. Interna revizija postupa kao nezavisna aktivnost provere operacija merenjem i ocenom adekvatnosti kontrole, kao i efektivnosti i efikasnosti izvršenja.

Institut internih revizora je objavio prvu deklaraciju odgovornosti za interne revizore 1947. godine (Statement of Responsibilities of Internal Auditing). To je bio značajan iskorak u to vreme, zbog toga što su se usuditi da pokažu da postoji briga internih revizora u vezi načina obavljanja poslovnih operacija. Ipak, naglasak je bio na „računovodstvenim i finansijskim pitanjima”. Kako su godine prolazile naglasak na računovodstvo je slabio, a revizija ostalih poslovnih aktivnosti je dobijala na značaju. Pet deklaracija objavljenih nakon 1947. (1957, 1971, 1976, 1981. i 1990.) pokazali su progres, menjanje i proširenje discipline. Posebna prekretnica u radu interne revizije bila je 1948. godine uvođenjem kategorije Operational Auditing, odnosno razvijanjem procedura operativne revizije - revizije poslovanja.

\section{ULOGA INTERNE REVIZIJE U ORGANIZACIJI}

Značaj interne revizije je znatno porastao poslednjih godina, sa zahtevom za iskusnim internim revizorima. Veliki propusti (neuspesi) u korporativnom upravljanju povećali su očekivanja učesnika što se tiče interne revizije. Interni revizori su prepoznati kao dragoceni eksperti koji donose širu perspektivu za upravljanje rizikom u njihovim organizacijama (McCaul, 2008).

Kao rezultat toga interna revizija je pretrpela dramatične promene koje su proširile njen delokrug na način koji joj omogućava da da veći doprinos organizaciji kojoj služi (Fadzil et al., 2005).

Gramling et al. (2004, str. 196) opisuju funkciju interne revizije kao "prozor u celokupnu kompaniju” koji služi kao „oči i uši menadžmenta”. Funkcija interne revizije sa ovakvom vrstom pristupa u organizaciji je u jedinstvenoj poziciji da služi kao dragoceni izvor (resurs) drugim partnerima korporativnog upravljanja, naime eksternim revizorima, odboru za reviziju i menadžmentu.

Kada su McCaul-a (2008) pitali koja je uloga funkcije interne revizije, on je objasnio da postoji izvestan broj izbora gde se utvrđuje fokus, svrha i stil poslovanja interne revizije. Kao rezultat sve većeg broja učesnika i sve većih očekivanja od aktivnosti interne revizije funkcija interne revizije se gura u razne pravce. Sa jedne strane, neke funkcije interne revizije funkcionišu da bi ispunile regulatorne zahteve i fokusiraju se skoro potpuno na finansijske kontrole, dok druge funkcije interne revizije prate efektivnost i efikasnost procesa poslovanja.

Opet neki drugi mogu utvrđivati smer fokusiranja na današnje procese, ljude i tehnologiju, ili možda na nove inicijative i sisteme budućnosti. Izazov za funkcionisanje interne revizije može predstavljati balansiranje zahteva za dodavanje materijalne vrednosti preduzeću svojim revizorskim radom, sa potrebom da obezbede objektivne preglede rizika i tako ispune svoju obavezu. Da bi interni revizori efikasno funkcionisali i korisnici revizorskih usluga (klijenti) treba da razumeju šta je to što internu reviziju čini aktivnošću za ostvarenje dodatne vrednosti. Nedostatak razumevanja može za rezultat imati zapažanje da interna revizija jednostavno predstavlja prepreku za postizanje ciljeva proizvodnje (Flesher \& Zanzig, 2000).

Interni revizori mogu da ostvare dodatnu vrednost entitetu obezbeđivanjem uveravanja, koje će omogućiti pravilno razumevanje i upravljanje izloženošću kompanije riziku. Interna revizija treba da ima ključnu ulogu u monitoringu profila rizika u kompaniji i utvrđivanju oblasti za unapređenje procesa upravljanja rizikom (Goodwin \& Kent, 2006). Kao što Walker et al. (2003, str. 52) tvrde, interna revizija može da „pomogne organizacijama da utvrde i ocene rizike tako što će usmeriti profesiju ka frontalnoj liniji upravljanja rizikom".

\section{RAZLIKA IZMEĐU INTERNE I EKSTERNE REVIZIJE}

Iako imaju neke zajedničke karakteristike interna i eksterna revizija imaju veoma različite ciljeve. Oni su objašnjeni u tabeli 1 .

Tabela 1. Glavne razlike između funkcija interne i eksterne revizije

\begin{tabular}{|c|c|c|}
\hline Kriterijumi & Interna revizija & Eksterna revizija \\
\hline $\begin{array}{l}\text { Pozicija unutar } \\
\text { organizacije }\end{array}$ & $\begin{array}{l}\text { Interni revizori predstavljaju deo organizacije. Njihove } \\
\text { ciljeve određuju profesionalni standardi, nadzorni od- } \\
\text { bor i menadžment. Njihovi primarni klijenti su menad- } \\
\text { žment i nadzorni odbor. }\end{array}$ & $\begin{array}{l}\text { Eksterni revizori ne predstavljaju deo organizacije, ali } \\
\text { ih ona angažuje. Njihovi ciljevi su određeni pre svega } \\
\text { statutom i od strane njihovog primarnog klijenta - nad- } \\
\text { zornog odbora. }\end{array}$ \\
\hline Ciljevi & $\begin{array}{l}\text { Delokrug rada internih revizora je sveobuhvatan - on slu- } \\
\text { ži organizaciji da postigne svoje ciljeve, unapredi procese } \\
\text { koji se odnose na poslovanje, upravljanje rizikom i inter- } \\
\text { nom kontrolom. } \\
\text { Brinući se za sve aspekte organizacije - finansijske i nefi- } \\
\text { nansijske - interni revizori se fokusiraju na buduće doga- } \\
\text { đaje kao rezultat stalnog pregleda i ocenjivanja kontrola i } \\
\text { procesa koje obavljaju. Na ovaj način se članovima nad- } \\
\text { zornog odbora i višem menadžmentu obezbeđuje uvera- } \\
\text { vanje koje im pomaže da obavljaju svoje dužnosti prema } \\
\text { organizaciji i njenim učesnicima. }\end{array}$ & $\begin{array}{l}\text { Primarni zadatak eksternih revizora je da obezbede ne- } \\
\text { zavisno mišljenje o finansijskim izveštajima organizacije } \\
\text { na godišnjem nivou. } \\
\text { Davanjem mišljenja o finansijskim izveštajima organi- } \\
\text { zacija doprinosi kredibilitetu i pouzdanosti finansijskih } \\
\text { izveštaja namenjenih njenim učesnicima. }\end{array}$ \\
\hline
\end{tabular}


Tabela 1. (nastavak)

\begin{tabular}{|c|c|c|}
\hline Kriterijumi & Interna revizija & Eksterna revizija \\
\hline Nezavisnost & $\begin{array}{l}\text { Interna revizija mora biti nezavisna od aktivnosti koje su } \\
\text { predmet revizije. }\end{array}$ & $\begin{array}{l}\text { Eksterna revizija je nezavisna od svog klijenta, organiza- } \\
\text { cije, s tim što je njena nezavisnost specifična za slobodne } \\
\text { profesije. }\end{array}$ \\
\hline $\begin{array}{l}\text { Predmet } \\
\text { revizije }\end{array}$ & Objektivnost i realnost finansijskih izveštaja. & $\begin{array}{l}\text { Celokupno poslovanje preduzeća (finansijski izveštaji, } \\
\text { računovodstveni sistem, ispitivanje sistema kontrola i sl.) }\end{array}$ \\
\hline Uloga revizije & Određena zakonom (Zakon o reviziji). & $\begin{array}{l}\text { Određena odlukom Uprave preduzeća ili Odbora za re- } \\
\text { viziju. }\end{array}$ \\
\hline $\begin{array}{l}\text { Područje koje } \\
\text { pokriva }\end{array}$ & $\begin{array}{l}\text { Finansijski izveštaji i povezana obelodanjivanja, } \\
\text { rizike finansijskog izveštavanja i upravljanje njima. }\end{array}$ & $\begin{array}{l}\text { Sve postupke i kategorije rizika, upravljanje njima uk- } \\
\text { ljučujući tok informacija širom preduzeća, i upravljanje. }\end{array}$ \\
\hline $\begin{array}{l}\text { Pristup } \\
\text { primenjen za } \\
\text { internu } \\
\text { kontrolu }\end{array}$ & $\begin{array}{l}\text { Interna revizija prati sve aspekte koji se odnose na si- } \\
\text { stem interne kontrole organizacije. }\end{array}$ & $\begin{array}{l}\text { Eksterna revizija prati sistem interne kontrole samo iz } \\
\text { perspektive materijalnosti (materijalnog značaja) što im } \\
\text { omogućava da eliminišu greške koje nisu značajne pošto } \\
\text { nemaju uticaja na finansijske rezultate. }\end{array}$ \\
\hline $\begin{array}{l}\text { Primena } \\
\text { revizije }\end{array}$ & Interna revizija obuhvata sve transakcije organizacije. & $\begin{array}{l}\text { Eksterna revizija obuhvata samo one transakcije koje do- } \\
\text { prinose finansijskim rezultatima i poslovanju organizacije. }\end{array}$ \\
\hline $\begin{array}{l}\text { Dinamika } \\
\text { revizije }\end{array}$ & $\begin{array}{l}\text { Interna revizija se obavlja tokom cele godine i ima speci- } \\
\text { fične zadatke utvrđene u skladu sa nivoom rizika za svaki } \\
\text { entitet koji je predmet revizije. }\end{array}$ & $\begin{array}{l}\text { Eksterna revizija predstavlja aktivnost sa godišnjom di- } \\
\text { namikom, po pravilu na kraju, odnosno početku godine. }\end{array}$ \\
\hline $\begin{array}{l}\text { Pristup koji } \\
\text { se primenjuje } \\
\text { kod rizika }\end{array}$ & $\begin{array}{l}\text { Utvrđuje i kvalifikuje ključne poslovne rizike da bi se oce- } \\
\text { nila verovatnoća događanja i uticaj na poslovanje. Daje } \\
\text { odgovarajuće preporuke kao rezultat ocenjivanja rizika. } \\
\text { Značaj rizika za planiranje aktivnosti interne revizije je } \\
\text { veoma veliki, tako što se ocenjivanje rizika obavlja zajed- } \\
\text { no sa drugim vrstama informacija kao što su finansijske } \\
\text { i operativne. }\end{array}$ & $\begin{array}{l}\text { Utvrđuje ključne transakcije i izloženost riziku za finan- } \\
\text { sijske izveštaje. } \\
\text { Eksterna revizija koristi informacije o rizicima za utvrđi- } \\
\text { vanje prirode, vremenskog perioda i neophodnih revizij- } \\
\text { skih procedura koje treba obaviti u oblasti koja je pred- } \\
\text { met revizije, uzimajući u obzir samo finansijske aspekte. }\end{array}$ \\
\hline $\begin{array}{l}\text { Razmatranje } \\
\text { faktora rizika } \\
\text { prema } \\
\text { Kolbertu }\end{array}$ & $\begin{array}{l}\text { Interna revizija razmatra bar sledeće faktore rizika } \\
\text { (Colbert, 1995): } \\
\text { - Etička klima (atmosfera) i pritisak na menadžment da } \\
\text { ispuni ciljeve; } \\
\text { - Kompetentnost, adekvatnost i integritet osoblja; } \\
\text { - Obim sredstava, likvidnost ili obim transakcija; } \\
\text { - Finansijski i ekonomski uslovi; } \\
\text { - Konkurentski uslovi; } \\
\text { - Uticaj propisa koji se odnose na klijente, dobavljače i } \\
\text { vladinih propisa; } \\
\text { - Datumi i rezultati prethodnih revizija; } \\
\text { - Stepen kompjuterizacije; } \\
\text { - Geografska rasprostranjenost poslovanja; } \\
\text { - Adekvatnost i efikasnost sistema interne kontrole; } \\
\text { - Organizacione, operativne, tehnološke ili ekonomske } \\
\text { promene; } \\
\text { - Mišljenja menadžmenta i računovodstvene procene; } \\
\text { - Prihvatanje revizijskih nalaza i preduzete korektivne } \\
\text { mere; }\end{array}$ & $\begin{array}{l}\text { Eksterna revizija razmatra sledeće faktore rizika } \\
\text { (Colbert, 1995): } \\
\text { - Upravljačkim operativnim i finansijskim odlukama } \\
\text { dominira jedna osoba; } \\
\text { - Stav menadžmenta u odnosu na finansijsko izveštava- } \\
\text { nje je nepropisno agresivan; } \\
\text { - Fluktuacija menadžmenta, naročito višeg računovod- } \\
\text { stvenog osoblja, je visoka; } \\
\text { - Menadžment stavlja nepropisni akcenat na ispunjava- } \\
\text { nje planova koji se odnose na zarade; } \\
\text { - Reputacija menadžmenta u poslovnoj zajednici je loša; } \\
\text { - Rentabilnost (profitabilnost) entiteta u odnosu na nje- } \\
\text { govu delatnost je neadekvatna i nekonzistentna; } \\
\text { - Osetljivost poslovnih rezultata na ekonomske faktore } \\
\text { je visoka; } \\
\text { - Stopa promena u delatnosti entiteta je visoka; } \\
\text { - Delatnost entiteta opada zbog mnogih poslovnih pro- } \\
\text { pusta (neuspeha); } \\
\text { - Organizacija je decentralizovana bez adekvatnog mo- } \\
\text { nitoringa; } \\
\text { - Interni ili eksterni slučaj (situacija) pokreće znatnu } \\
\text { sumnju kada je u pitanju sposobnost entiteta da nasta- } \\
\text { vi svoje poslovanje; } \\
\text { - Preovlađuju sporna ili teška (ozbiljna) računovodstve- } \\
\text { na pitanja; } \\
\text { - Postoje značajne i neuobičajene transakcije vezane za } \\
\text { - Pruge partnere izvan uobičajenog toka poslovanja; } \\
\text { verovatnih lažnih iskaza (tvrdnji) otkrivenih za vreme } \\
\text { revizije finansijskih izveštaja su značajni; } \\
\text { poseduje dovoljno informacija od prethodnog revizora. }\end{array}$ \\
\hline
\end{tabular}


Tabela 1. (nastavak)

\begin{tabular}{|c|c|c|}
\hline Kriterijumi & Interna revizija & Eksterna revizija \\
\hline Izveštaji & $\begin{array}{l}\text { Nadzornom odboru i višem menadžmentu koji su u } \\
\text { okviru strukture upravljanja u organizaciji. }\end{array}$ & $\begin{array}{l}\text { Akcionarima ili članovima koji su izvan strukture uprav- } \\
\text { ljanja organizacijom. }\end{array}$ \\
\hline $\begin{array}{l}\text { Delokrug } \\
\text { (obuhvaćenost) }\end{array}$ & $\begin{array}{l}\text { Sve kategorije rizika, njihovo upravljanje, uključujući } \\
\text { izveštavanje o njima. }\end{array}$ & Finansijski rizici, rizici finansijskog izveštavanja. \\
\hline Menadžment & $\begin{array}{l}\text { Izveštaji izvršnom menadžmentu - administrativno. } \\
\text { Gradi odnose u organizaciji da bi se obezbedilo da se } \\
\text { problemi pravovremeno identifikuju i reše. }\end{array}$ & $\begin{array}{l}\text { Primarno izveštaji odboru za reviziju o finansijama i in- } \\
\text { ternoj kontroli. }\end{array}$ \\
\hline Fokus & $\begin{array}{l}\text { Obezbeđuje finansijske i operativne usluge, usluge uve- } \\
\text { ravanja, konsultativne usluge, usluge koje se odnose na } \\
\text { upravljanje, kompjutere i prevare. }\end{array}$ & $\begin{array}{l}\text { Pre svega potvrđuje (atestira) finansijske izveštaje i in- } \\
\text { ternu kontrolu. }\end{array}$ \\
\hline $\begin{array}{l}\text { Odbor za } \\
\text { reviziju }\end{array}$ & $\begin{array}{l}\text { Izveštaji se dostavljaju direktno odboru za reviziju. Obez- } \\
\text { beđuje mišljenja o poslovnim rizicima organizacije, fi- } \\
\text { nansijskim izveštajima, sistemu interne kontrole, i nivou } \\
\text { usaglašenosti sa zakonima, propisima i politikama. }\end{array}$ & $\begin{array}{l}\text { Potvrđuje tačnost finansijskih izveštaja odboru za reviziju } \\
\text { i potvrđuje ocenjivanje od strane menadžmenta internih } \\
\text { kontrola finansijskog izveštavanja. Obezbeđuje ažurira- } \\
\text { nje tekućih računovodstvenih objavljivanja i njihov uticaj } \\
\text { na organizaciju. }\end{array}$ \\
\hline
\end{tabular}

Nezavisna je u odnosu na organizaciju.

\begin{tabular}{|c|c|}
\hline Nezavisnost & $\begin{array}{l}\text { Pokazuje nezavisnost i objektivnost u pristupu, ali nije } \\
\text { nezavisna od organizacije; nezavisna je od aktivnosti } \\
\text { koja je predmet revizije, ali predstavlja integralni deo } \\
\text { organizacije. }\end{array}$ \\
\hline Rezultati & $\begin{array}{l}\text { Utvrđuje probleme, daje preporuke, i pomaže u dono- } \\
\text { šenju odluka. }\end{array}$ \\
\hline $\begin{array}{l}\text { Pristup pri- } \\
\text { menjen za } \\
\text { internu kon- } \\
\text { trolu }\end{array}$ & $\begin{array}{l}\text { Interna revizija prati sve aspekte koji se odnose na si- } \\
\text { stem interne kontrole organizacije. } \\
\text { Vezano za SAD, u skladu sa SOX } 404 \text { obezbeđuje uvera- } \\
\text { vanje da su finansijski i operativni sistemi interne kon- } \\
\text { trole adekvatni i efikasni; i da su sistemi interne kontrole } \\
\text { svake aktivnosti u organizaciji (uključujući kontrolu fi- } \\
\text { nansijskog izveštavanja) na adekvatan način planirani, } \\
\text { efektivni i efikasni. Može da pomogne u dokumentova- } \\
\text { nju internih kontrola, testiranju internih kontrola, i/ili } \\
\text { obezbeđenju inputa (informacija) menadžmentu u vezi } \\
\text { sa donošenjem zaključaka o efikasnosti plana i poslova- } \\
\text { nja. }\end{array}$ \\
\hline
\end{tabular}

\begin{tabular}{|c|c|}
\hline Nezavisnost & $\begin{array}{l}\text { Pokazuje nezavisnost i objektivnost u pristupu, ali nije } \\
\text { nezavisna od organizacije; nezavisna je od aktivnosti } \\
\text { koja je predmet revizije, ali predstavlja integralni deo } \\
\text { organizacije. }\end{array}$ \\
\hline Rezultati & $\begin{array}{l}\text { Utvrđuje probleme, daje preporuke, i pomaže u dono- } \\
\text { šenju odluka. }\end{array}$ \\
\hline $\begin{array}{l}\text { Pristup pri- } \\
\text { menjen za } \\
\text { internu kon- } \\
\text { trolu }\end{array}$ & $\begin{array}{l}\text { Interna revizija prati sve aspekte koji se odnose na si- } \\
\text { stem interne kontrole organizacije. } \\
\text { Vezano za SAD, u skladu sa SOX } 404 \text { obezbeđuje uvera- } \\
\text { vanje da su finansijski i operativni sistemi interne kon- } \\
\text { trole adekvatni i efikasni; i da su sistemi interne kontrole } \\
\text { svake aktivnosti u organizaciji (uključujući kontrolu fi- } \\
\text { nansijskog izveštavanja) na adekvatan način planirani, } \\
\text { efektivni i efikasni. Može da pomogne u dokumentova- } \\
\text { nju internih kontrola, testiranju internih kontrola, i/ili } \\
\text { obezbeđenju inputa (informacija) menadžmentu u vezi } \\
\text { sa donošenjem zaključaka o efikasnosti plana i poslova- } \\
\text { nja. }\end{array}$ \\
\hline
\end{tabular}

Pristup primenjen za internu kontrolu
Primenjuje zakonske propise i obezbeđuje potrebna korigovanja da bi se postigla finansijska tačnost.

Eksterna revizija prati sistem interne kontrole samo iz perspektive materijalnosti (materijalnog značaja) što im omogućava da eliminišu one greške koje nisu značajne pošto nemaju uticaja na finansijske rezultate.

Vezano za SAD, utvrđuje rizike i ocenjuje kontrole finansijskog izveštavanja za svrhu planiranja revizije. Planiranje revizije ima za rezultat dokumentovanje povezanosti utvrđenog rizika revizije i ocenjivanja internih kontrola. Povezanost se utvrđuje ocenjivanjem rizika od lažnih iskaza u svakom delu finansijskih izveštaja i planiranjem revizijskih procedura za bavljenje ovim rizikom. Nadgleda pristup koji menadžment koristi u primeni SOX 404 uključujući rezultate u raznim ključnim fazama. Obavlja reviziju rada menadžmenta i uključenih predstavnika i priprema izveštaj o potvrđivanju pouzdanosti i tačnosti izveštavanja u skladu sa SOX 404.

Eksterna revizija se bavi samo prevarama u finansijskoj oblasti. Plan za reviziju uključuje faze za otkrivanje prevara. Prikuplja informacije potrebne za utvrđivanje rizika lažnog prikazivanja, koje je od materijalnog značaja zbog prevare ispitivanjem menadžmenta i drugih u entitetu o rizicima od prevara. Razmatra faktore rizika od prevara, analitičke procedure i suštinsko testiranje u fazama planiranja i rada na terenu.

\begin{tabular}{lll}
\hline Preporuke & $\begin{array}{l}\text { Daje preporuke za korektivne mere menadžmentu u } \\
\text { izveštajima o reviziji. }\end{array}$ & Daje preporuke za korektivne mere. \\
\hline Praćenje & $\begin{array}{l}\text { Obavlja praćenje sa klijenatima da bi se obezbedilo da se } \\
\text { obavi posao koji će rešiti probleme. }\end{array}$ & Ograničava praćenje na finansijske oblasti. \\
\hline $\begin{array}{l}\text { Korisnici } \\
\text { revizorskih } \\
\text { izveštaja }\end{array}$ & $\begin{array}{l}\text { Vlasnici (akcionoari), potencijalni investitori, državne } \\
\text { agencije. }\end{array}$ & $\begin{array}{l}\text { Menadžment (uprava), nadzorni odbor, eksterna i dr- } \\
\text { žavna revizija. }\end{array}$ \\
\hline
\end{tabular}




\section{POREĐENJE INTERNIH I EKSTERNIH REVIZORA}

Eksterni revizori se često oslanjaju na druge profesionalce (stručnjake), prilikom revizije finansijskih izveštaja svojih klijenata (Haron et al., 2004). Eksterni revizori se uglavnom oslanjaju na rad funkcije interne revizije klijenta, prilikom obavljanja dužnosti eksterne revizije pošto su i jedni i drugi revizori zabrinuti za to da li postoje pravilne kontrole. Haron et al. (2004) navode da oslanjanje na rad internih revizora treba da omogući da se smanji broj časova koje je potrebno provesti u radu na reviziji, kako bi se omogućilo smanjenje naknade za usluge revizije.

Interni i eksterni revizori poseduju različiti potencijal koji udružuju da bi povećali efikasnost revizije. Na primer, funkcija interne revizije sprovodi većinu svog vremena radeći u istoj kompaniji; kao rezultat toga oni se bolje upoznaju sa kulturom i poslovanjem te kompanije. Na taj način im se omogućava da vide stvari koje eksterni revizori ne bi videli. Pošto eksterni revizori rade za više klijenata, oni su izloženi većem broju raznih finansijskih problema i zbog toga mogu da otkriju stvari (probleme) kojima se interni revizori ranije nisu bavili (Wood, 2005). Radeći zajedno odnos između internih i eksterni revizora treba da predstavlja jednu zajedničku podršku i saradnju da bi se unapredio ukupan kvalitet revizije (O'Leary \& Stewart, 2007).

Pored toga, unapređena saradnja između ovih strana može da omogući internim revizorima da neposrednije prate nedostatke u kontroli, koje utvrde eksterni revizori i povećaju nivo unapređenja. Radeći zajedno obe strane mogu da izvrše veći pritisak na menadžment, da ih zaštiti od korišćenja preterano agresivnih računovodstvenih principa nego što to bilo koja strana može nezavisno da primenjuje (Wood, 2004).

Kao posledica toga, primećuju se brojne razlike u praksi postoje pitanja koja se odnose na stepen do kojeg interni revizori treba da učestvuju u eksternoj reviziji. Izvesne profesionalne računovođe sve više zastupaju mišljenje da veća saradnja između internih i eksternih revizora, ukljućujući veće korišćenje internog revizora u eksternoj reviziji, obezbeđuje efikasniji delokrug revizije.

Međutim, drugi smatraju da interni revizori ne treba da se fokusiraju na oblasti koje su predmet eksterne revizije (Morrill \& Morrill, 2003).

\section{ZAKLJUČAK}

Iz različitih razloga neke funkcije interne revizije i odbor direktora nisu adekvatno diferencirali zadatke interne revizije od zadataka eksterne revizije, nego su često poistovetili internu reviziju sa poslovima eksterne revizije, i time doveli do potpune neefikasnosti takve funkcije interne revizije. Velika većina internih revizora su prvobitno bili eksterni revizori. To stečeno iskustvo obezbeđuje značajnu obuku pri razvoju programa revizije, oceni sistema, analiziranju transakcija, pronalaženju grešaka i pripremi radnih dokumenata. Ali ukoliko se u projektima interne revizije primenjuju tehnike eksterne revizije, rezultati mogu biti nedelotvorni. Takvi revizori mogu promašiti poentu celokupne revizije. Aktivnosti ove dve discipline, interne i eksterne revizije, se mogu preklapati u oblasti provere računovodstvene kontrole. Ipak, zbog različitih ciljeva, razlike su mnogo veće od sličnosti.
Dok je nadzorni odbor u osnovi odgovoran za održavanje efektivnog upravljanja organizacijom, uveren da je organizacija „pod kontrolom”, širina i kompleksnost poslovnih rizika i kontrola koja se na njih odnosi doveli su do toga da menadžment mnogo više očekuje od interne revizije. Interni revizori nisu više „oni koji jurišaju na ranjenike posle završene bitke, već su tu ili da bitno spreče, ili da postanu integralni deo fabrike oružja kompanije, ako do borbe dođe".

Ako se razmatra osnovni razlog za korišćenje revizorskih usluga, onda je povod za eksternu reviziju regulatorni zahtev za nezavisno potvrđivanje (sertifikaciju) da su finansijske informacije koje se predstavljaju akcionarima i finansijskoj zajednici objektivne i tačne. Odnosno, glavna odgovornost eksternih revizora bi bila potvrđivanje valjanosti finansijskih izveštaja. S druge strane, interna revizija je pre svega uzrokovana željom menadžmenta da raspolaže internim resursima, koji se fokusiraju na procese u organizaciji i obezbeđuju tačnost, efikasnost i efektivnost poslovanja, ispitujući rizike, kontrolu i procese upravljanja.

\section{LITERATURA}

Colbert, J.L. (1995). Risk: internal and external auditors operate from two different, official definitions of risk. Internal Auditor.

Corfe, T. (2002). The role of internal audit after Enron. ACCA Internal Audit Bulletin, 14, pp. 3-5.

Cosserat, G.W. (2004). Modern Auditing. Hoboken, NJ: John Wiley \& Sons.

England, H. (2003). Objectives and Role of Internal Audit. ACCA Internal Audit Bulletin, 15, pp. 8-10.

Engle, T.J. (1999). Managing External Auditor Relationships. Internal Auditor, August, pp. 19-24.

Fadzil, F.H., Haron, H., \& Jantan, M. (2005). Internal auditing practices and internal control system. Managerial Auditing Journal, 20(8), 844-866. doi:10.1108/02686900510619683

Felix, W., Gramling, A.A., \& Maletta, M. (1998). Co-ordinating Total Audit Coverage: The Relationship between Internal and External Auditors. Altamonte Springs, FL: The Institute of Internal Auditors.

Felix, W., Gramling, A.A., \& Maletta, M. (2001). The contribution of internal audit as a determinant of external audit fees and factors influencing this contribution. Journal of Accounting Research, 39(3), 513-534. doi: 10.2139/ ssrn. 284197

Felix, W., Gramling, A.A., \& Maletta, M. (2005). The Influence of Non-Audit Service Revenues and Client Pressure on External Auditors' Decisions to Rely on Internal Audit. Contemporary Accounting Research, 22(1), 31-53. doi:10.1506/JN7X-B51L-V45W-4U7R

Financial Reporting Council. (2008). The Combined Code on Corporate Governance. Preuzeto 9. septembra 2015. sa https://www.frc.org.uk/getattachment/1a875db9-b06e4453-8f65-358809084331/The-Combined-Code-on-Corporate-Goverance.aspx

Flesher, D.L., \& Zanzig, J.S. (2000). Management accountants express a desire for change in the functioning of internal auditing. Managerial Auditing Journal, 15(7), 331-337. doi:10.1108/02686900010344601 
Goodwin, J. (2004). A comparison of internal audit in the private and public sectors. Managerial Auditing Journal, 19(5), 640-650. doi:10.1108/02686900410537766

Goodwin-Stewart, J., \& Kent, P. (2006). The use of internal audit by Australian companies. Managerial Auditing Journal, 21(1), 81-101. doi:10.1108/02686900610634775

Gramling, A.A. (1999). External Auditors' Reliance on Work Performed by Internal Auditors: The Influence of Fee Pressure on This Reliance Decision. Auditing: A Journal of Practice and Theory, 18, 117-138. doi: 10.1108/02686901011054845

Gramling, A.A., \& Vandervelde, S.D. (2006). Assessing internal audit quality. Internal Auditing, 21(3), 26-33

Gramling, A.A., Maletta, M.J., Schneider, A., \& Church, B.K. (2004). The role of the internal audit function in corporate governance: A synthesis of the extant internal auditing literature and directions fro future research. Journal of Accounting Literature, 23, 194-244.

Gray, I., \& Manson, S. (2000). The audit process: Principles, practice and cases. Cornwall: Thompson Learning.

Haron, H., Chambers, A., Ramsi, R., \& Ismail, I. (2004). The reliance of external auditors on internal auditors. Managerial Auditing Journal, 19(9), 1148-1159.

Institute of Internal Auditors. (2000). Internal Auditing: Adding Value across the Board. Corporate Brochure, IIA.

International Federation of Accountants. (2007). Handbook of international auditing, assurance, and ethics pronouncements. New York, USA: IFAC.

Mautz, R. (1984). Internal and external auditors: how do they relate? Corporate Accounting, 3(4), 56-58.
McCaul, L. (2008). Enhancing the value of Internal Audit: Ten Key Questions. Accountancy Ireland, 38(3), 34-37.

Millichamp, A. (2002). Auditing. London: Continuum Books.

Morrill, C., \& Morrill, J. (2003). Internal auditors and the external audit: a transaction cost perspective. Managerial Auditing Journal, 18(6/7), 490-504.

O'Leary, C., \& Stewart, J. (2007). Governance Factors Affecting Internal Auditors' Ethical Decision-Making: An Exploratory Study. Managerial Auditing Journal, 22(8), 787-808.

Peacock, E.\& Pelfrey, S. (1989). How internal auditors view the external audit? The Internal Auditor, 46, 48-54.

Porter, B., Simon, J., \& Hatherly, D. (2003). Principles of External Auditing. Chichester, England: John Wiley \& Sons.

Sawyer. L., Difftenhofer, M., Scheiner, J. (2003). Sawyer's Internal auditing The Practice of Modern Internal Auditing. Altamonte Springs, Fla: The Institute of Internal Auditors.

Službeni glasnik RS. (2013). Zakon o reviziji. Službeni glasnik RS, broj 62/2013.

The Institute of Internal Auditors. (2013). International Professional Practices Framework (IPPF). USA: The IIA Research Foundation.

Walker, P.L., Shenkir, W.G., \& Barton, T.L. (2003). ERM in practice. Internal Auditor, 60(4), 51-55.

Wood, D.A. (2004). Increasing value through internal and external auditor coordination. USA: The IIA Research Foundation.

\section{DIFFERENT ROLES AND RESPONSIBILITIES OF INTERNAL AND EXTERNAL AUDIT}

\section{Abstract:}

The management of companies and other organizations does not differentiate between the roles and responsibilities of internal and external audit, which often leads to identifying internal audit activities as external audit activities. In such circumstances, internal audit is not as efficient as it should be and it does not contribute to achieving the desired objectives of the organization, since it is often mistaken for external audit, even though they are two quite different professions. In order to solve the problem of insufficient effectiveness of internal audit in such companies, it is necessary to start from the analysis of the internal and external audit goals. The main activity of both audits is to provide assurance. The major difference between them is related to the issue they give assurance about, i.e., what type of assurance is given and to whom, and for which period is such assurance given. Whereas external audit provides assurance about the accuracy and objectivity of financial statements, internal audit gives assurance on the effectiveness and efficiency of risk management, internal controls and governance processes, in relation to the overall operations of an organization, not only in the domain of financial reporting, but in relation to the overall operations of an organization.

Thus, one should be able to distinguish between the subjects of internal and external audit and define their golas, as well as to specify how their responsibilities are set up and supervised.

\section{Key words:}

internal audit,

external audit,

the role of audit,

audit responsibility. 